Please refer to the published version when citing:

Cohen, S.A., Higham, J.E.S. \& Reis, A.C. (2013). Sociological barriers to developing sustainable discretionary air travel behaviour. Journal of Sustainable Tourism, DOI:

10.1080/09669582.2013.809092.

\title{
Sociological Barriers to Developing Sustainable Discretionary Air Travel Behaviour
}

\author{
Scott A. Cohen \\ University of Surrey, United Kingdom \\ James E.S. Higham \\ University of Otago, New Zealand \\ Arianne C. Reis \\ Southern Cross University, Australia
}

\begin{abstract}
Encouraging positive public behaviour change has been touted as a pathway for mitigating the climate impacts of air travel. There is, however, growing evidence that two gaps, one between attitudes and behaviour, and the other between practices of "home" and "away", pose significant barriers to changing discretionary air travel behaviour. This article uses both modern sociological theory on tourism as liminoid space, and postmodern theory that views identities as contextual, to provide a deeper understanding of why these gaps occur in the context of tourism spaces. Based on 50 in-depth consumer interviews in Australia, Norway and the United Kingdom, our findings confirm that tourism spaces are often subject to lower levels of environmental concern than daily domestic contexts. The majority of participants reduced, suppressed or abandoned their climate concern when in tourism spaces, and rationalised their resulting behavioural contradictions. Only a minority held there was no difference between the environmental sustainability of their practices in domestic situations versus those on holiday. These findings suggest that scope for voluntary positive behaviour change in the air travel context is limited and will not come without stronger intervention, which is a key finding for policy makers seeking reductions in air travel's climate impacts.
\end{abstract}

Keywords - Flying, climate change, attitude-behaviour gap, home and away, identity, behaviour change

\section{Introduction}

Mitigating the greenhouse gas emissions from air travel is one of the most challenging aspects of society's response to climate change (Monbiot, 2007). Whereas research from the transport and tourism sectors agrees that air travel emissions are a key environmental challenge (Barr, Shaw, \& 
Coles, 2010; Becken, 2007; Scott, 2011; Scott, Hall, \& Gössling, 2012), how to best address the climate impacts of discretionary air travel remains an elusive problem (Cohen, Higham, \& Cavaliere, 2011). Scope for further efficiency gains in aircraft emissions are declining (Scott, Peeters, \& Gössling, 2010), and there is not yet a global climate policy for international commercial aviation (Duval, 2012). Signatories of airlines in the United Kingdom, for instance, instead of choosing to transform supply or raise consumer awareness of air travel's climate impacts, presently pin their hopes for a sustainable aviation future on technology, alternative fuels and operational innovations (Sustainable Aviation, 2011). In the context of industry resistance to wholesale supply changes and in the absence to date of a global market-based mechanism for aviation, such as carbon trading, the concept of encouraging voluntary public behaviour change has been presented as a mechanism for moving discretionary air travel consumption towards a more sustainable pathway (Barr, Gilg, \& Shaw, 2011; Miller, Rathouse, Scarles, Holmes, \& Tribe, 2010).

Encouraging pro-environmental behaviour change has been discussed in environmental psychology more generally (e.g. Steg \& Vlek, 2009) and with regards to climate impacts specifically (e.g. Barr et al., 2011; Semenza et al., 2008). The prospects for positive behaviour change in the context of the public's air travel behaviour has been the focus of recent empirical attention, with studies finding gaps between awareness and attitudes (Hares, Dickinson, \& Wilkes, 2010) and attitudes and behaviour (Kroesen, 2013; Miller et al., 2010). These works point to a breakdown in consumer decision-making processes in the context of discretionary air travel behaviour, in which environmental awareness and pro-environmental attitudes are not in practice translating to voluntary sustained behavioural changes (McKercher, Prideaux, Cheung, \& Law, 2010). Barr et al. (2010), who sought to understand tourists' environmental concern in relation to a wider scope of everyday lives and their processes of decision-making, found that participants who were committed to environmental practices at home were unwilling to reduce holiday air travel. This suggests that there are fundamental barriers to changing discretionary air travel behaviour, even amongst proenvironmental consumers.

This article takes Barr et al.'s (2010) finding that environmental concern may not transcend "home" to the context of "away" as its departure point. Based on 50 in-depth semi-structured interviews carried out in Australia, Norway and the United Kingdom, we illustrate behavioural consistencies and inconsistencies with respect to climate change amongst consumers in both everyday domestic (home) and tourism (away) practices. In contrast to Barr et al. (2010), however, we use both modern and postmodern sociological theory to explain why these seemingly contradictory consumption decisions occur. Specifically, we engage modern theory on tourism as liminoid space (Turner, 1982) and postmodern theory that suggests that personal identity (and consequently behaviour) is inconsistent and performed differently across varying contexts (Bell, 2008; Edensor, 2001). The findings of our research, framed within these theoretical perspectives, hold important implications for the viability of climate change mitigation strategies that rely, at least in part, on encouraging voluntary behaviour change amongst consumers.

\section{Climate concern and discretionary air travel}

Tourism, as an oil intensive industry (Becken, 2010), has come under increasing pressure to move to a sustainable emissions path (Gössling, 2009). It is widely acknowledged that the tourism industry is 
implicated in climate change in terms of both cause and effect (Pang, McKercher, \& Prideaux, 2012). Of the $4.4 \%$ of global carbon emissions for which tourism is directly accountable (Peeters \& Dubois, 2010), 40\% can be conservatively attributed to tourist air travel (Gössling, 2009). To disentangle tourist air travel, however, from a wider range of discretionary mobilities, such as visiting friends and relatives, or business travel coupled with tourism activities, is a challenging proposition. Regardless, in comparison with alternatives such as rail, road and sea-based passenger modes, air travel is the most harmful for the climate system (Gössling \& Peeters, 2007) and presents one of the tourism industry's largest challenges if it seeks to sustain contemporary aeromobility-dependent tourism practices (Burns \& Bibbings, 2009).

Correspondingly, much of the recent academic concern over tourism's climate change impacts has centred upon issues surrounding tourist air travel (Gössling \& Upham, 2009), including how these issues intersect with tourism demand and behaviour (e.g. Gössling, Scott, Hall, Ceron, \& Dubois, 2011; Mair 2011). In conjunction with this research line there has been growing interest in whether consumer awareness about climate change manifests itself in perceptual (Becken, 2007; Cohen \& Higham, 2011; Huebner, 2012), attitudinal (Higham \& Cohen, 2011) and/or intended (or actual) behavioural changes in tourism practices (Kroesen, 2013; McKercher \& Prideaux, 2011; Miller et al., 2010). These studies largely suggest a dissonance between awareness or attitudes and actual behavioural change. For instance, on one hand Cohen and Higham (2011, p. 331) report a growing movement of UK consumers who reflect a "carbon conscience" in approaching air travel decisions, and Gössling, Peeters, \& Scott (2008, p. 875) observe that "pro-environmental concerns are clearly emerging among consumers, and may play a significant role in travel decisions in the future". On the other hand, Miller et al. (2010) find public reluctance in the UK to actually take fewer holidays in order to reduce personal carbon impacts, and Kroesen (2013) measured in the Netherlands an inconsistency between pro-environmental awareness and air travel behaviour. These latter studies support McKercher \& Prideaux's (2011) observation that tourism and air transport are low on personal environmental agendas, at least in terms of manifest behavioural changes.

This attitude-behaviour gap is not unique to discretionary air travel practices: it has also been identified as a problem for work-related air travel (Lassen, 2010), and sustainable tourism (Antimova, Nawijn, \& Peeters 2012) and ethical consumption more widely (Bray, Johns, \& Kilburn, 2011). The gap is reported in the context of other modes of transport, such as automobiles (Anable, 2005), and has been described as a barrier to the ability of individuals to reduce emissions, as part of what Whitmarsh, Seyfang, and O'Neill $(2011$, p. 58) term the public's "carbon capability". In the context of discretionary air travel, however, the issue seems to be compounded by consumer perceptions that tourism spaces are not "appropriate sites in which to be environmentally conscious", with behavioural differences between home and tourism settings reported (Barr, Shaw, \& Coles, 2011, p. 1243). Barr et al. (ibid) go on to argue that tourism research needs to be better connected to wider knowledge on pro-environmental behaviour, so that this additional gap between "home" and "away", which further complicates the attitude-behaviour gap, can be understood. We concur and consequently suggest that by turning to modern and postmodern sociological theory in tourism, complementary explanatory concepts are available that may help us to better understand these behavioural inconsistencies. 


\section{Liminoid space and contextualised performances of identity}

Despite suggestions that tourism practices are increasingly blended into the fabric of everyday life (Edensor, 2007; Franklin \& Crang, 2001; Larsen, 2008), tourism still largely occurs as a bounded experience outside the rhythms of the day-to-day, is often experienced as extraordinary (Tung \& Ritchie, 2011), and frequently involves conspicuous consumption (Carr, 2005). With tourism typically experienced as an event set apart from the day-to-day, it is unsurprising that few studies, with the exception of Barr et al. (2010), have sought to understand tourist environmental concern in relation to a wider scope of everyday lives and daily decision-making.

Both a modern sociological perspective that positions tourism experiences as an escape from one's everyday self (Cohen and Taylor, 1992), and a postmodern perspective that views selves, and in turn behaviours, as performed and contextually dependent (Bell, 2008), suggest that just because individuals act or perform one way in a situation, does not mean that behaviours transfer consistently across contexts. This has implications for understanding the transferability of proenvironmental attitudes and behaviours across differing life contexts, as each of these theoretical perspectives suggests that behaviour is situationally dependent.

Within modern motivational literature on tourism, the need to escape has long been recognised as a key motivator for travel (Crompton, 1979; Dann, 1977). Crompton (1979, p. 416) observes that the desire to "escape from a perceived mundane environment", or alternatively, the tedium of routine, forms one of the major motives driving tourist behaviour. Under this view tourism is "essentially a temporary reversal of everyday activities - it is a no-work, no-care... situation" (Cohen, 1979, p. 181). Breaking from everyday routine is linked to Turner's (1982) description of the "liminoid", a secularised term conveyed from ritual studies, which is characterised as a departure from the structure of everyday life (Lett, 1983). Liminality is associated with three phases: separation, "limen" and re-aggregation, with limen signifying a metaphorical threshold that one may pass through as a departure from the structure of one's everyday life in society (Turner, 1982). Sharpley (2003, p. 5-21) applies the liminoid to tourism experiences, noting that whilst away on holiday, tourists may feel "temporarily freed from... household chores, social commitments and, generally, the behavioural norms and values of their society." Furthermore, Kim and Jamal (2007, p. 184) suggest that within "liminal touristic space, conventional social norms and regulations are often temporarily suspended as tourists take advantage of the relative anonymity and freedom from community scrutiny."

Indeed, the notion of tourism occurring in liminoid space melds well with more recent academic literature that holds that tourism is a furtive ground for extraordinary experiences (see Morgan, Lugosi, \& Ritchie 2010; Tung \& Ritchie, 2011). These two-fold discourses, of escape and, in turn, extraordinary experience, attempt to map out tourism space as fundamentally different from the everyday, contributing to a dichotomised framing of "home" and "away". This dualism, between tourism and, in contrast, everyday life, views tourism as liminal, exotic and pleasurable, whereas the day-to-day is represented as bound by rules, and as ordinary and boring (see Larsen, 2008 for a critique of this dualism). An important implication of this modernist perspective on tourism is that behaviour in (liminoid) tourism spaces will be markedly different to behaviour at "home", due to the lack of rules, sense of escape and suspension of behavioural norms associated with the former. 
Albeit based on quite different premises to those of modernity, a postmodernist sociological approach, like the above modernist position, also draws into question the degree to which performances of identity, and hence behaviour, are likely to consistently transcend contexts. A performance perspective (Bell, 2008; Edensor, 2001), arising from Goffman's (1959) work on selves, in which individuals perform different "faces" depending on the social situation, suggests that personal identities are too fragmented, contextually-dependent and relational (Finnegan, 1997; McAdams, 1997; Vaughan \& Hogg, 2002) to expect behavioural consistency. This means that individuals have multiple selves that are "often demonstrated in different interpersonal roles or relationships", and which may "contradict or conflict with each other depending on situation or context" (Bond \& Falk, 2013, in press). Tourism, specifically, has been suggested as a space to "display and create new identities, even if only for the duration of the holiday" (Hibbert, Dickinson \& Curtin, 2013, in press). Thus tourism practices may be characterised by fleeting performances of identity, in which new identities may be tried out, played with, and discarded, while other identity aspects can be emphasised, or hidden, all depending on social context. Within this postmodernist perspective, dissonance between attitudes and behaviours, and inconsistencies in patterns of behaviour across contexts are both easily reconciled because consistency is not presumed from the start.

These modernist and postmodernist worldviews, with behaviour dichotomised between "here" and "there" in the former, and performances of identity fragmented and unstable across contexts in the latter, may seem distant to our focus on consumer climate concern as it relates to discretionary air travel. However, these issues are paramount if seeking to mitigate tourism's climate change impacts through strategies that attempt to nudge consumers towards pro-environmental behaviour. With identities, and in turn, attitudes and behaviours, largely contingent on social context, there can be no certain expectation that consumer climate concern in daily life practices will necessarily transfer across to, or be sustained in, tourism settings.

\section{Study methodology}

The empirical material that follows draws from a wider multi-national research project on consumer attitudinal and behavioural responses to climate change in the contexts of discretionary air travel practices and day-to-day domestic living. Other parts of the broader project have examined consumer attitudes towards, and perceptions of, the climate impacts of long-haul air travel from the United Kingdom (Cohen \& Higham, 2011) and Norway (Higham \& Cohen, 2011) to New Zealand, and the phenomenon of "'binge flying" (Cohen et al., 2011, p. 1071). We adopted a critical interpretive research paradigm with a subjectivist epistemological position (Denzin \& Lincoln, 2005). Our philosophical stance was influenced by our shared position that aviation greenhouse gas emissions are a significant contributor to anthropogenic climate change and need to be mitigated through various social, political and technical avenues. Our joint view is that significant reductions in levels of discretionary air travel among consumers represent a key part of the societal response to climate change.

We considered our study participants to be "...individuals whose opinions are valued, and valid" (Sedgley, Pritchard, \& Morgan, 2012, p. 954) and as such followed the advice of Fontana and Frey (2005) and did not superimpose our worldviews on the study participants. Although we were 
non-activist in our approach, our research was transformative (Pernecky \& Jamal, 2010) in that asking the questions we did was an act of raising self-awareness on the part of the study participants, stimulating reflection upon the potential consequences of their discretionary air travel behaviours. These decisions were aligned with our aim to elicit deeply subjective personal perspectives on air travel behaviour and climate change.

The empirical material is drawn from a cross-section of consumers in three nations: Australia, Norway and the United Kingdom, where tensions exist between global climate change and the conspicuous consumption of aeromobility (Burns \& Bibbings, 2009; Randles \& Mander, 2009). While we recognise that the Australian public does not have the same options for more sustainable travel as Europeans, owing to the nation's distance from other countries and a less developed and less significant domestic rail network, the governments of these three nations have all been actively engaged in discourses addressing the urgency of climate change mitigation (Gössling, 2009; Hares et al., 2010; Høyer, 2000; Zeppel, 2012), with Australia recently headlining in the media for its new carbon tax (BBC News, 2012). Specifically, we set out to achieve in-depth insights into awareness of, attitudes towards, and personal behavioural responses to global climate change, in both domestic living and in tourism contexts. Extensive qualitative materials were generated through one-to-one open-ended personal interviews (Fontana \& Frey, 2005), an approach selected for the flexibility it offers in identifying and exploring issues in detail (Jennings, 2001).

The qualitative materials are derived from 50 semi-structured open-ended interviews conducted in Coffs Harbour, Australia (April-July 2011), Stavanger, Norway (June-July 2009), and Bournemouth, United Kingdom (July 2009). The locations where interviews were conducted were based on convenience, as members of the research team were based at Southern Cross University (Australia), the University of Stavanger (Norway) and Bournemouth University (UK) during the fieldwork when the respective interview programmes were conducted. Participants were recruited using convenience and snowball sampling techniques. Access to participants initially relied on key informants in each study site, both from within and outside the university contexts. Selection criteria were that participants self-identify as Australian, Norwegian or British nationals and be willing to be interviewed face-to-face in English. We aimed to access a relatively equal gender distribution across a broad age range, with a minimum age for participation of 18 years. The interviews were conducted at neutral sites, lasted 30 to 60 minutes, and were digitally recorded. The main themes addressed in the interviews were awareness of and attitudes towards anthropogenic climate change, domestic behavioural responses to climate change in day-to-day living and changes in travel decision-making and behaviour in relation to climate change, including a focus on discretionary air travel practices. A copy of the programme used to semi-structure the interviews can be found as a supplementary file on the web based version of this paper, however this was employed as a flexible guide that allowed each interview to move in different directions as it developed. Interviewing concluded in each national study site when evidence of data saturation emerged.

The 50 interview participants included 25 females and 25 males (Australia 10 females: 10 males; Norway 8: 7; UK 7: 8) with ages from 18 to 67 (Table 1). Their occupational status reflected 21 industry workers from a variety of professional and non-professionalised fields, nine students, seven university academics, seven university administrators, four unemployed persons, one teacher, and one retiree. The participants spanned a range of education levels, however the majority were highly educated and moderately affluent (albeit less so in the Australian context), reflecting the sampling 
being driven out of a university context. We recognise that educational, financial and social backgrounds may have significant bearing on the participants' attitudes and behaviours. Our collective participant profile mostly reflects the attitudes and behaviours of individuals with the resources to make frequent flying personally relevant. The majority of the participants, particularly in the European contexts, were in fact highly aeromobile, with air travel at least once annually routine, with several flights per year (and sometimes per month) not uncommon, for a mix of reasons including leisure, business, and/or visiting friends and relatives. The participant profile is one of relative privilege such that we do not claim representation of Australian, Norwegian or British society.

The interviews were transcribed and following repeated independent readings and annotation, we applied a triple blind thematic analysis approach in manually interpreting the data (Patton, 2002). This approach involved reducing the data into categories guided by the study participants' narratives, but without losing sight of the research aims, a process that allowed for the identification of emergent themes (Miles \& Huberman, 1994; O'Reilly, 2005). The analytical perspectives applied in this paper, of liminoid space and contextualised identities, were not part of the initial research design but rather emerged as relevant during analysis of the data. During the immersive blinded process we acted as three independent critical analysts and then engaged in collective "analyst triangulation" (Patton, 2002). This aimed to ensure trustworthiness by checking for congruity of interpretations, blind spots and multiple ways of interpreting the data (Lincoln \& Guba, 1985). Our respective blinded interpretations were largely in accordance; however, some individual interpretations did highlight specific data blind spots that were revealed in our collaborative discussions. Through triangulation we set out to promote dependability (through interpreter triangulation), credibility (through theoretical triangulation between our empirical material and existing theories) and transferability (through rich description of the context to facilitate analytical transfer) (Decrop, 2004). 
Table 1 Summary profile of Australian, Norwegian and British interview programme participants

\begin{tabular}{|c|c|c|c|c|c|}
\hline Pseudonym & Gender & Age & Nationality & Occupation & Highest qualification \\
\hline Alex & $\mathrm{M}$ & 49 & Australian & Unemployed & Undergraduate \\
\hline Danielle & $\mathrm{F}$ & 31 & Australian & Industry work & Undergraduate \\
\hline Jessamin & $\mathrm{F}$ & 18 & Australian & Undergraduate student & High school \\
\hline Tina & $\mathrm{F}$ & 36 & Australian & Industry work & Undergraduate \\
\hline Lauren & $\mathrm{F}$ & 47 & Australian & University administrator & Undergraduate \\
\hline Josi & $\mathrm{F}$ & 29 & Australian & Industry work & Technical diploma \\
\hline Martin & M & 57 & Australian & Industry work & Technical diploma \\
\hline Grant & M & 56 & Australian & Unemployed & High school \\
\hline Justin & M & 24 & Australian & Postgraduate student & Masters \\
\hline Camilla & $\mathrm{F}$ & 24 & Australian & Industry work & Undergraduate \\
\hline Kevin & $M$ & 57 & Australian & Postgraduate student & Masters \\
\hline Brian & M & 29 & Australian & Industry work & Technical diploma \\
\hline Kay & $\mathrm{F}$ & 46 & Australian & University administrator & Masters \\
\hline Bruce & M & 58 & Australian & University administrator & Undergraduate \\
\hline Tom & M & 47 & Australian & Industry work & Technical diploma \\
\hline Lili & $\mathrm{F}$ & 43 & Australian & Unemployed & Undergraduate \\
\hline Ian & $M$ & 43 & Australian & Academic & $\mathrm{PhD}$ \\
\hline Eric & $M$ & 38 & Australian & Unemployed & Technical diploma \\
\hline Amy & $\mathrm{F}$ & 43 & Australian & Industry work & High school \\
\hline Jen & $\mathrm{F}$ & 30 & Australian & Teacher & Undergraduate \\
\hline Frode & $M$ & 37 & Norwegian & Industry work & Masters \\
\hline Rita & $\mathrm{F}$ & 34 & Norwegian & Industry work & Masters \\
\hline Bjørn & M & 41 & Norwegian & Industry work & $\mathrm{PhD}$ \\
\hline Silje & $\mathrm{F}$ & 45 & Norwegian & Industry work & Masters \\
\hline Svein & M & 35 & Norwegian & Industry work & High school \\
\hline Tone & $\mathrm{F}$ & 58 & Norwegian & Postgraduate student & Masters \\
\hline Ida & $\mathrm{F}$ & 52 & Norwegian & University administrator & Masters \\
\hline Grete & $\mathrm{F}$ & 27 & Norwegian & Postgraduate student & Undergraduate \\
\hline Lars & M & 53 & Norwegian & Academic & PhD \\
\hline Pål & M & 34 & Norwegian & Industry work & Masters \\
\hline Hilda & $\mathrm{F}$ & 67 & Norwegian & Retiree & Masters \\
\hline Håkon & M & 48 & Norwegian & Industry work & Undergraduate \\
\hline Johannes & M & 57 & Norwegian & Academic & $\mathrm{PhD}$ \\
\hline Anette & $\mathrm{F}$ & 35 & Norwegian & Industry work & Masters \\
\hline Grethe & $\mathrm{F}$ & 27 & Norwegian & Postgraduate student & Masters \\
\hline Cindy & $\mathrm{F}$ & 42 & British & University administrator & High school \\
\hline Jack & M & 35 & British & Industry work & Undergraduate \\
\hline Grace & $\mathrm{F}$ & 36 & British & University administrator & Masters \\
\hline Jessica & $\mathrm{F}$ & 48 & British & University administrator & High school \\
\hline Ruby & $\mathrm{F}$ & 41 & British & Industry work & High school \\
\hline Amy & $\mathrm{F}$ & 30 & British & Academic & $\mathrm{PhD}$ \\
\hline Hannah & $\mathrm{F}$ & 48 & British & Postgraduate student & Masters \\
\hline Oliver & M & 30 & British & Academic & Masters \\
\hline Thomas & $M$ & 38 & British & Academic & Masters \\
\hline Harry & $M$ & 40 & British & Industry work & Undergraduate \\
\hline Daniel & M & 18 & British & Undergraduate student & High school \\
\hline Mia & $\mathrm{F}$ & 21 & British & Undergraduate student & High school \\
\hline James & $M$ & 63 & British & Academic & $\mathrm{PhD}$ \\
\hline William & M & 42 & British & Industry work & Undergraduate \\
\hline Lewis & M & 39 & British & Industry work & Undergraduate \\
\hline
\end{tabular}




\section{Consistencies between home and away}

Our study revealed significant inconsistencies in the participants' climate sensitivities and related behaviours between domestic day-to-day and tourism contexts. The findings were remarkably similar across the study participants from each of the three nations, in that the majority of the participants reduced, suppressed or abandoned their climate concern when in tourism spaces. A minority of the participants, however, held there was no difference between the environmental sustainability of their practices in domestic decisions versus those made whilst away on holiday. For instance, Tom (Australian, 47) explained - "I think the same as I think about the impacts in everyday life, no different in holidays ... they are the same decisions that I'd made if I was at home." Oliver (British, 30) maintained a similar view:

Exactly the same principles would apply. If I'm staying in a hotel, I wouldn't dream of leaving the room with the lights on, for example. If I'm in a hotel, I'm not going to boil more water than I need. I'm not going to stand under the shower for ten minutes longer than is necessary.

Such statements were typically used to discount the notion that economic motives underpinned some pro-environmental behaviour. William (British, 42) placed this issue in a stark light - "When we go to Florida, I wouldn't just leave the air-conditioning on all day and all night because I'm not paying for it. I would be responsible about it." Yet this statement avoids the issue that the energy use of air conditioning is insignificant alongside the decision to fly to Florida. Svein (Norwegian, 35), when asked how important money was in his attitudes towards the environment whilst on holiday, responded:

For me, economics is not a big issue. I'm not above average in Norway. We're so rich and comfortable here and what I want more of in my life is other qualities than monies and luxury and that kind of wealth. So it's not motivated by money.

Svein prioritised consuming ethically across the different facets of his life. As he recognises, however, this is a position of privilege largely made available through his citizenship in an affluent nation.

For each of these study participants, tourism practices were viewed holistically as part of a broader lifestyle in which consistency was sought in values, attitudes and behaviours across different facets of life. Barr et al. (2010, p. 475) describe this notion of a "sustainable lifestyle" as implying that "individuals would demonstrate a series of commitments across lifestyle practices, not merely as part of their routine, but also in tourism contexts." Such a perspective counters the notion of tourism as liminoid space (Sharpley, 2003) and, to a degree, identities as contextually contingent (Finnegan, 1997; Vaughan \& Hogg, 2002), by displaying behavioural consistency across domestic day-to-day and tourism spaces. It furthermore illustrates an entanglement of tourism in daily life (Larsen, 2008), whereby everyday environmental concerns and those associated with tourism are enmeshed. Svein further elaborated a view of the everyday and holidays as inextricably interlinked, with the carbon savings accumulated through practices such as cycling to work seen as nonsensical when positioned alongside the prospect of flippant discretionary air travel: "So you can't ride your bike to your job and use a plane everywhere without thinking about it - it would be stupid." This type of consistent rational actor approach, however, was relatively rare amongst the study participants. 


\section{Inconsistencies between home and away}

As opposed to achieving alignment between approaches to environmental sustainability in everyday practices and those whilst on holiday, participants evidenced that tourism spaces are often the stage for performances of less stringent, suppressed or non-existent climate concern and more environmentally destructive consumption practices. This supports the work of Barr et al. (2010; 2011), and others' observations (e.g. Lassen, 2010; Kroesen, 2013) that air travel behaviour fails to correlate significantly with broader environmental awareness. These study participants, who may be committed to environmental practices in and around the home (e.g. reducing waste and energy use, buying organic, "ethical" purchasing, cycling instead of driving) are indeed often unwilling to reduce holiday air travel. For instance, Harry (British, 40), whose undergraduate degree was paradoxically in environmental management, undertook a range of practices in everyday life to mitigate his climate impact, but was unwilling to transfer sustainable practices to the realm of discretionary air travel, where he privileged speed and convenience over environmental sustainability:

I have a small car with a small engine and that is purely from a global warming point of view, from a pollution point of view. I do see the impact [of air travel] and I would get on an airplane and go on a long-haul flight because I want to travel, I want to get to this place, and I can't think of another way to do it reasonably quickly, reasonably safely, minimum of fuss. It's the convenience, it boils down to that.

Harry thus illustrates how the two gaps, one in attitude/behaviour and the other in home/away are interlinked, whereby his pro-environmental attitudes lead to positive environmental behaviour in domestic life, yet a gap remains between those attitudes and how his behaviour manifests in the context of tourism travel. In order to get "away", he is willing to suspend the climate sensitivities he performs at "home" which maintain his identification with environmental management. Likewise, Jen (Australian, 30) recognised through the interview process an inconsistency between climate concern in her daily life and tourism practices, and suggested that convenience took priority in holiday flying decisions:

I never really thought about climate change in relation to travel much and it's interesting to actually start thinking about it, because I think about it in every other area, I mean, I do when I'm driving my car but not when I'm actually going on holiday... it's probably something that a lot of people don't, you don't think about it, because you're just thinking about the convenience of flying somewhere.

Also supporting behavioural inconsistency between home and away, Frode (Norwegian, 37) took great interest in reducing waste in his everyday life, but chose not to buy voluntary carbon offsets or reduce his frequent air travel:

I'm not buying CO2 quota on the planes when I'm flying, I'm not buying that. What I'm doing - I'm recycling quite a bit. I think that's the most important thing that I'm doing I'm quite concerned about how I distribute my garbage. So good with garbage, not that good with travel - travel like always. 
Frode's concern about managing his garbage, but lack of concern in the context of air travel, may reflect the deep socially embedded nature of environmental practices such as recycling within his society, which may have become habit. Quite oppositely, Randles and Mander (2009) suggest that tourist air travel itself has become habit, for some sections of society, and that there are only "flickerings" of evidence of consumer environmental concern over aviation. Bjørn (Norwegian, 41), however, argued that decisions, rather than being habit, are often consciously weighed, but typically cannot be attributed to a singular motivation, such as climate concern. In his case, as a father, climate concern needed to be balanced against a range of other personal considerations, such as cost, time and comfort:

These values are a little bit related to how much does it cost for me also, I must admit. I feel like a bit schizophrenic in terms of climate, because on one end I want to contribute and at the same time I have all these requirements during every day with small kids, going to shopping, all this practical stuff you have to do. There is a set of motivating factors, and environmental is one aspect of many. And the importance of that aspect is partly related your situation in life at the present moment.

Bjørn's words suggest that the primacy given to environmental values may vary through the lifecycle, as other demands, such as family, compete in consumption decisions. His identity as a father is thus in conflict with his environmental values, reflecting how interpersonal relationships and responsibilities can shape mobility decisions (Hibbert et al., 2013), with particular aspects of identity coming to the fore in different social contexts. Bjørn describes this as "schizophrenic", but a perspective of identities as multiple and performed (Bell, 2008), as discussed earlier, would view such behaviour as commonplace. This explanation supports also Ryan's (1997) observation that motivations are often multidimensional and contextual. Thus, while participants may have behaved in particular ways due to some extent to climate concern, such behaviours typically emerged out of a mix of motivational and context-specific factors, with the implication that pro-environmental behaviour was unlikely to remain consistent as situational factors shifted. These findings, in which behavioural inconsistencies between home and away were typical, therefore further substantiate McKercher et al.'s (2010) view that "consumer reaction to climate change issues can be described as contradictory at best".

\section{Liminoid tourism spaces}

Several of the participants perceived tourism practices as existing largely outside of the social norms that they use, consciously or subconsciously, to structure their behaviour in everyday life. In this sense, tourism space was experienced as liminoid (Kim \& Jamal, 2007), and hence perceived as relatively free from the behavioural norms and values of the day-to-day. As such, Pål, (Norwegian, 34), when asked if he saw a difference in energy consumption decisions he might take in daily life versus on a holiday, replied:

I think so - because when you're on holiday you're in a different mode. You are somewhere else and you want to get the most out of it and go home and be filled with impressions and experiences. 
Pål viewed the spaces of tourism as extraordinary, wherein climate change sensitivity took backseat to securing memorable experiences, in theory on offer through tourist activities (Morgan et al., 2010; Tung \& Ritchie, 2011). Ida (Norwegian, 52) emphasised making the most of her holidays, which did not include taking time to consider its climate impact - "I'm not stopping and thinking, no. I'm there and I want to see much and do what I want to do." Similarly, Eric (Australian, 38) expressed reluctance to associate holiday spaces with environmental concern of any type, and placed his own level of enjoyment, and desire to relax, as the key factors driving his decision-making:

[W] hatever I will do on a holiday it will come more out of my personal enjoyment of doing whatever it may be, and yeah, I won't be consciously thinking ok, does this activity impact that? That's not my thought process. If I am on holiday I am there to bloody relax, not feel more responsible and guilty that I am killing the world.

These participants attached too high an importance to their holidays to consider adapting them because of climate change, such as through travelling less, taking a domestic holiday instead of international (Miller et al., 2010), or travelling slowly by more environmentally benign transport modes such as rail or coach (Dickinson, Robbins, \& Lumsdon, 2010). This mirrors the findings of Hares et al. (2010), in which there is reluctance to forgo the perceived positive benefits made accessible by tourist air travel in order to reduce personal emissions.

For Rita (Norwegian, 34), both the importance of escaping to an attractive overseas destination to relax and the trip's corresponding economic cost outweighed concern over the climate impacts of her holidays. She attributed this to the relative infrequency of her holidaying:

Holiday trips are maybe once a year and other issues would be more important - where to go and economic questions - would be more important on my annual travels. The things I can do every day are easier to be conscious about and to make a decision about then what you do once a year. Because then it's more important to me to go to a nice place and relax for two weeks.

Rita's viewpoint contrasts, at least in a corporeal sense, the notion of tourism as part of everyday life (Edensor, 2007; Franklin \& Crang, 2001; Larsen, 2008), instead viewing it as extraordinary and helping to perpetuate a dualistic separation between daily domestic and less frequent tourism experiences. For Rita, holidays are liminoid spaces of pleasure where everyday rules and social norms are relaxed (Kim \& Jamal, 2007). The infrequency of tourism travel was particularly significant amongst the Australian participants, for whom most holiday flying was long-haul, overseas and justified through its uncommonness. This point on the difference in regularity between domestic and tourism decisions was also cited as an important factor by Tone (Norwegian, 58):

Daily life is more important. I'm more concerned about daily life because we don't travel all the time. It's [flying] kind of abstract, because you are not doing this every day and it is a little bit away from you when you have landed and then you go home.

Tone illustrates how physical distancing from spaces of daily life through air travel contributes to experiences of tourism spaces as liminoid: her words reflect Turner's (1977) phases of liminality, in which one separates from "normal" life (take-off), passes through the "limen", or metaphorical threshold (via flight), into a transitory state of liminality characterised by a perceived lack of 
structure (at a new destination), and finally re-aggregates by returning (flying) home. Notably, such a cycle assumes (often wrongly) a lack of familiarity with the social norms of the destination.

Nonetheless, the relative infrequency of tourism practices, combined with their typical occurrence in spaces outside of everyday life, provided justification for sustainability practices to be temporarily suspended. A temporary suspension of environmental norms when on holidays lends support to Barr et al.'s (2010, p. 475) observation that a sustainable lifestyle will only exist once "individuals are able to transfer their behaviours between contexts, as part of an embedded set of lifestyle practices." As discretionary air travel is often employed as a gateway to liminoid experiences, tourism practices when viewed from this conceptual perspective pose a significant barrier to achieving sustainable lifestyles.

\section{Contextualised performances of consumer concern}

Rather than consistent performances of identity aligned with an embedded set of lifestyle practices, through a commitment to reducing climate impacts across all life contexts, many of the participants narrated performances of consumer concern that were contingent upon context, reflecting how multiple identities can be performed depending on the social situation at hand (Bell, 2008; Bond \& Falk, 2013). In some cases, the contradiction between striving for sustainable practices in everyday life, only for a single long-haul flight taken to exceed annual per capita sustainable emission levels (Gössling, Haglund, Kallgren, Revahl, \& Hultman 2009), was openly acknowledged:

I think it's a contradiction. I think a lot of people do it. But you kind of, you kind of try to put it back of your mind and try not to worry about it. Well, you think, I'm seeing the world and it's great for the kids to see the world. So you try to put it to one side. Silly really. (Ruby, British, 41)

A lot of the work I do ... focuses on improving resilience to the effects of climate change... I recycle, train, live with the least sort of environmental footprint impact as I can ... I am aware [of] the impact that planes flying every which way, all of the time, has on the atmosphere and things like that... but it probably doesn't influence my travel decision. (Camilla, Australian, 24)

In another instance, a participant who regularly stayed in the UK and went camping for her holidays, both because of lower costs and pro-environmental attitudes, admitted that if her financial circumstances were to change, that she would probably not be able to resist taking tourism trips via long-haul air travel - "Say I won a load of money tomorrow - I'd probably go [to New Zealand]. It's awful, isn't it? You feel guilty but you justify it to yourself in some respect" (Grace, British, 36). Thus, for Grace, her travel behaviour was contingent on the social and economic context in which she might be positioned, rather than an enduring set of core values or a steadfast environmental identity. Equally, Tom (Australian, 47) further speculated on the contextually contingent climate concern of others:

[A] lot of people got those solar power subsidy deals and, you know, a lot of those people are concerned about climate change and did it for that reason, but those same people would be more than happy to jump in a plane and fly to Europe given the opportunity. 
For another participant, different performances were offered between home and away, which while inconsistent, were not recognised as conflictive with the participants' environmental values:

I probably don't think about it actually. You know what, I went to Turkey last year, and it was 40 degrees and we had air conditioning and we left it on. We went out and left the air conditioning on. And I don't think that I, for one moment, thought about the effects on the environment. And l've even done an environmental degree. (Harry, British, 40)

For Harry, who closely monitored his domestic energy consumption at home, both air travel and energy usage once in the destination were subject to a lower level of climate concern than in daily life practices.

The inconsistency between these different "faces" performed depending on context, which constitute what we may term "multiple environmental identities", were not experienced by the participants as a source of concern that needed any mediation or reconciliation. Multiple malleable and fluid identities (McAdams, 1997), with climate change sensitivities adapted to suit the participant's needs in each situation, were narrated to make sense of and justify what may be externally perceived as behavioural contradictions. Lewis (British, 39), who was gravely concerned over the implications of climate change for the futures for his two young children, reflected this capacity for multiple identity performances in justifying the environmental impact from his last holiday in Florida:

[T]here were four families with four cars and we drove everywhere every single day to a different a location to do something. And even when you're in those locations chances are you're using amenities that are extremely wasteful on electricity and emissions as well. So you think a lot less about the environmental impacts then. You're in an apartment, you pay for it, it's not yours, whether you go out and leave the lights on chances are you're a lot less environmentally aware when you're on holiday than when you're not.

As illustrated through these latter examples, not only the decision to fly, but also a range of other tourism practices with environmental consequences relating to accommodation, activities and ground transport, reflect inconsistent performances of consumer concern between "home" and "away". Such seemingly contradictory consumption decisions, however, are routine within postmodern theory that assumes personal identity (and consequently behaviour) is inconsistent and performed differently across varying contexts.

\section{Conclusion}

In this article we have sought to further the understanding of why there is an attitude/behaviour gap, compounded by a dissonance between "home" and "away" (Barr et al., 2010; 2011), which makes voluntary consumer behaviour change in the context of discretionary air travel an intractable situation. The paper does have limitations: it is based on Western countries, with a participant profile that is for the most part highly educated and moderately affluent. Nonetheless, empirical evidence from our study participants, who were in the main highly aeromobile, demonstrates that 
tourism spaces are often subject to lower levels of environmental concern than day-to-day contexts. Although there was some evidence of consistency amongst the study participants between the environmental sustainability of their domestic practices and those made when on holiday, such cases were exceptional. More common was the tendency to subject tourism settings to less stringent, or even to consider them as exempt from, climate concern.

This paper echoes the findings of other works that suggest that the public is largely unwilling to voluntarily change their holiday flying behaviour for environmental reasons (Barr et al., 2010; Cohen et al. 2011; Hares et al. 2010; Miller et al. 2010), a resistance also found in work-related air travel (Lassen, 2010), and in flying more generally (Kroesen, 2013). This paper is, however, unique in providing an in-depth sociological explanation of why an attitude/behaviour gap exists between climate change sensitivity and discretionary air travel. Drawing heavily from insights from the field of knowledge in tourism studies, the paper responds to calls to better connect tourism research to knowledge on pro-environmental behaviour (Barr et al., 2011). In doing so, it provides a nuanced understanding of why behavioural inconsistencies exist between public climate concern and actual holiday flying practices.

Whether these behavioural inconsistencies and contradictions are understood as a modern expression of tourism practices occurring in liminoid space (Turner, 1982), or as a postmodern reflection of multiple, contextually-dependent identities (Bell, 2008), the implications are the same. Our consistent findings from study participants not only shows how these sociological theories are powerful devices in explaining both attitude-behaviour and home-away gaps within discretionary air travel decisions, but also provides a firmer basis for evaluating the prospects of sustained behavioural change amongst the travelling public. We argue that scope for positive behaviour change in the context of discretionary air travel practices is limited. In this sense we provide theoretical and empirical support for the suggestion of McKercher et al. (2010, p. 297) that "government intervention may be required to create meaningful behavioural change in tourism patterns."

These findings are of importance to policy makers who may seek reductions in the climate impacts of discretionary air travel through even a partial reliance on public behavioural change. Given the declining scope for technical gains in aircraft energy efficiency (Scott et al., 2010) and in the absence of a global market-based mechanism (e.g. carbon trading) for the aviation sector (Duval, 2012), governments' ambitions to encourage pubic behaviour change (see Barr et al., 2011 and Miller et al., 2010 in the UK case) may be misguided in the context of the tourism and travel sectors. Strategies that seek to tackle these issues, whether through education or media, by aiming to nudge individual lifestyles towards less carbon-intensive consumption choices, need to be tempered with an awareness that environmental identities, like other aspects of personal identities, cannot be relied upon to lead to consistent behaviour. This is a significant challenge for the governance of climate change and aviation.

Academia, in cooperation with third-sector pressure groups, needs to focus on changing the attitudes of policy makers and key industry stakeholders, at national and supranational levels, to help pave the difficult road towards strong (global) policy interventions aimed at reducing the greenhouse gas emissions from the aviation industry. This paper demonstrates why scope for positive voluntary public behaviour change in the context of discretionary air travel is limited. When 
set alongside the wealth of evidence that corroborates this conclusion (e.g. Barr et al., 2011; Hares et al., 2010; Kroesen, 2013; Lassen, 2010; Miller et al., 2010), it is abundantly clear that urgent policy interventions for stronger climate governance of aviation are required. Future research therefore needs to now turn to the issues that may hinder policy development in this area, such as concerns over social equity in the distribution of air travel, cultural nuances across nation states, including non-Western countries, which may impede (or facilitate) collective agreements, structural barriers in alternatives to short-haul air travel, and how a redistribution of receipts from tourism and air travel more generally can be accommodated. Such work will be critical to the international policy interventions that are clearly necessary, to put in place and implement binding mitigation targets for the aviation industry.

\section{References}

Anable, J. (2005). "Complacent car addicts" or "Aspiring Environmentalists"? Identifying travel behaviour segments using attitude theory. Transport Policy, 12, 65-78.

Antimova, R., Nawijn, J., \& Peeters, P. (2012). The awareness/attitude gap in sustainable tourism: A theoretical perspective. Tourism Review, 67(3), 7-16.

Barr, S., Gilg, A., \& Shaw, G. (2011). "Helping people make better choices": Exploring the behaviour change agenda for environmental sustainability. Applied Geography, 31, 712-720.

Barr, S., Shaw, G., \& Coles, T. (2011). Times for (Un)sustainability? Challenges and opportunities for developing behaviour change policy. A case-study of consumers at home and away. Global Environmental Change, 21, 1234-1244.

Barr, S., Shaw, G., Coles, T., \& Prillwitz, J. (2010). "A holiday is a holiday": Practicing sustainability, home and away. Journal of Transport Geography, 18(3), 474-481.

BBC News (2012). Australia introduces controversial carbon tax. Retrieved 30 April 2013 from http://www.bbc.co.uk/news/world-asia-18662560.

Becken, S. (2007). Tourists' perception of international air travel's impact on the global climate and potential climate change policies. Journal of Sustainable Tourism, 15(4), 351-368.

Becken, S. (2010). A critical review of tourism and oil. Annals of Tourism Research, 38(2), 359-379.

Bell, E. (2008). Theories of Performance. Sage: Los Angeles.

Bond, N. \& Falk, J. (2013). Tourism and identity-related motivations: Why am I here (and not there)? International Journal of Tourism Research, DOI: 10.1002/jtr.1886.

Bray, J., Johns, N., \& Kilburn, D. (2011). An exploratory study into the factors impeding ethical consumption. Journal of Business Ethics, 98(4), 597-608.

Burns, P., \& Bibbings, L. (2009). The end of tourism? Climate change and societal challenges. 21st Century Society, 4(1), 31-51. 
Carr, N. (2005). Poverty, debt, and conspicuous consumption: University students tourism experiences. Tourism Management, 26, 797-806.

Cohen, E. (1979). A phenomenology of tourist experience. Sociology, 13, 179-202.

Cohen, S.A. \& Higham, J.E.S. (2011). Eyes wide shut? UK Consumer perceptions on aviation climate impacts and travel decisions to New Zealand. Current Issues in Tourism, 14(4), 323-335.

Cohen, S.A., Higham, J.E.S., \& Cavaliere, C.T. (2011). Binge flying: Behavioural addiction and climate change. Annals of Tourism Research, 38(3), 1070-1089.

Cohen, S., \& Taylor, L. (1992). Escape Attempts: The Theory and Practice of Resistance to Everyday Life. London: Routledge.

Crompton, J. (1979). Motivations for pleasure vacation. Annals of Tourism Research, 6(4), 408-424.

Dann, G. (1977). Anomie, ego-enhancement and tourism. Annals of Tourism Research, 4(4) 184-194.

Decrop, A. (2004). Trustworthiness in qualitative tourism research. In J. Phillimore \& L. Goodson (Eds). Qualitative research in tourism: Ontologies, epistemologies and methodologies. (pp. 156-169). London: Routledge.

Denzin, N. K., \& Lincoln, Y. S. (2005). Introduction: The discipline and practice of qualitative research. In N. K. Denzin \& Y. S. Lincoln (Eds.), The Sage handbook of qualitative research (3rd ed.) (pp. 1-32). Thousand Oaks: Sage Publications.

Dickinson, J., Robbins, D., \& Lumsdon, L. (2010). Holiday travel discourses and climate change. Journal of Transport Geography, 18(3), 482-489.

Duval, D.T. (2012). Critical issues in air transport and tourism. Tourism Geographies, DOI: $10.1080 / 14616688.2012 .675581$

Edensor, T. (2001). Performing tourism, staging tourism. Tourist Studies, 1(1), 59-81.

Edensor, T. (2007). Mundane mobilities, performances and spaces of tourism. Social \& Cultural Geography, 8(2), 199-215.

Finnegan, R. (1997). "Storying the self": Personal narratives and identity. In H. Mackay (Ed.), Consumption and Everyday Life (pp. 66-111). London: Sage Publications.

Fontana, A., \& Frey, J. H. (2005). The interview: From neutral space to political involvement. In N. K. Denzin \& Y. S. Lincoln (Eds.), The Sage handbook of qualitative research (3rd ed.) (pp. 695-728). Thousand Oaks: Sage Publications.

Franklin, A., \& Crang, M. (2001). The trouble with tourism and travel theory? Tourist Studies, 1(1), 522.

Goffman, E. (1959). The Presentation of self in everyday life. Middlesex: Penguin Books.

Gössling, S. (2009). Carbon neutral destinations: A conceptual analysis. Journal of Sustainable Tourism, 17(1), 17-37. 
Gössling, S., Haglund, L., Kallgren, H., Revahl, M., \& Hultman, J. (2009). Swedish air travellers and voluntary carbon offsets: Towards the co-creation of environmental value. Current Issues in Tourism, 12(1), 1-19.

Gössling, S., \& Peeters, P. (2007). "It does not harm the environment!" An analysis of industry discourses on tourism, air travel and the environment. Journal of Sustainable Tourism, 15(4), 402417.

Gössling, S., Scott, D., Hall, C.M., Ceron, J-P. \& Dubois, G. (2012). Consumer behaviour and demand responses of tourists to climate change. Annals of Tourism Research, 39(1), 36-58.

Gössling, S., Peeters, P., \& Scott, D. (2008). Consequences of climate policy for international tourist arrivals in developing countries. Third World Quarterly, 29, 5, 873-901.

Gössling, S., \& Upham, P. (Eds.). (2009). Climate change and aviation: Issues, challenges and solutions. London: Earthscan.

Hares, A., Dickinson, J., \& Wilkes, K. (2010). Climate change and the air travel decisions of UK tourists. Journal of Transport Geography, 18(3), 466-473.

Hibbert, J., Dickinson, J.E. \& Curtin, S. (2013). Understanding the influence of interpersonal relationships on identity and tourism travel. Anatolia: An International Journal of Tourism and Hospitality Research, DOI: 10.1080/13032917.2012.762313.

Higham, J.E.S., \& Cohen, S.A. (2011). Canary in the coalmine: Norwegian attitudes towards climate change and extreme long-haul air travel to Aotearoa/New Zealand. Tourism Management, 32(1), 98105.

Høyer, K. (2000). Sustainable tourism or sustainable mobility? The Norwegian case. Journal of Sustainable Tourism, 8(2), 147-160.

Huebner, A. (2012). Public perceptions of destination vulnerability to climate change and implications for long-haul travel decisions to small island states. Journal of Sustainable Tourism, 20(7), 939-951.

Jennings, G. (2001). Tourism Research. Milton: John Wiley \& Sons.

Kim, H., \& Jamal, T. (2007). Touristic quest for existential authenticity. Annals of Tourism Research, 34(1), 181-201.

Kroesen, M. (2013). Exploring people's viewpoints on air travel and climate change: Understanding inconsistencies. Journal of Sustainable Tourism, 21(2), 271-290.

Larsen, J. (2008). De-exoticizing tourist travel: Everyday lives and sociality on the move. Leisure Studies, 27(1), 21-34.

Lassen, C. (2010). Environmentalist in business class: An analysis of air travel and environmental attitude. Transport Reviews, 30(6), 733-751. 
Lett, J.W. (1983). Ludic and liminoid aspects of charter yacht tourism in the Caribbean. Annals of Tourism Research, 10(1), 35-56.

Lincoln, Y.S. \& Guba, E.G. (1985). Naturalistic Inquiry. Newbury Park, CA: Sage Publications.

Mair, J. (2011). Exploring air travellers' voluntary carbon-offsetting behaviour. Journal of Sustainable Tourism, 19(2), 215-230.

McAdams, D.P. (1997). The case for unity in the (post)modern self: A modest proposal. In R.D. Ashmore \& L. Jussim (Eds.), Self and Identity: Fundamental Issues (pp. 46-78), New York: Oxford University Press.

McKercher, B., \& Prideaux, B. (2011). Are tourism impacts low on personal environmental agendas? Journal of Sustainable Tourism, 19(3), 325-345.

McKercher, B., Prideaux, B., Cheung, C., \& Law, R. (2010). Achieving voluntary reductions in the carbon footprint of tourism and climate change. Journal of Sustainable Tourism, 18(3), 297-317.

Miles, M. B., \& Huberman, A. M. (1994). Qualitative data analysis: An expanded sourcebook. Thousand Oaks: Sage Publications.

Miller, G., Rathouse, K., Scarles, C., Holmes, K., \& Tribe, J. (2010). Public understanding of sustainable tourism. Annals of Tourism Research, 37(3), 627- 645.

Monbiot, G. (2007). Heat: How to stop the planet burning. London: Penguin Books.

Morgan, M., Lugosi, P., \& Ritchie, J.R.B. (Eds.). (2010). The tourism and leisure experience: Consumer and managerial perspectives. Clevedon: Channel View.

O’Reilly, K. (2005). Ethnographic methods. London: Routledge.

Pang, S.F.H., McKercher, B., \& Prideaux, B. (2012). Climate change and tourism: An overview. Asia Pacific Journal of Tourism Research, DOI: 10.1080/10941665.2012.688509

Patton, M. Q. (2002). Qualitative research and evaluation methods. Thousand Oaks: Sage Publications.

Peeters, P., \& Dubois, G. (2010). Tourism travel under climate change mitigation constraints. Journal of Transport Geography, 18(3), 447-457.

Pernecky, T., \& Jamal, T. (2010). (Hermeneutic) phenomenology in tourism studies. Annals of Tourism Research, 37(4), 1055-1075.

Randles, S., \& Mander, S. (2009). Practice(s) and ratchet(s): A sociological examination of frequent flying. In S. Gössling \& P. Upham (Eds.), Climate change and aviation: Issues, challenges and solutions (pp. 245-271). London: Earthscan.

Ryan, C. (1997). The Tourist Experience: A New Introduction. London: Cassell.

Sedgley, D., Pritchard, A., \& Morgan, N. (2012). "Tourism poverty" in affluent societies: Voices from inner-city London. Tourism Management, 33, 951-960. 
Scott, D. (2011). Why sustainable tourism must address climate change. Journal of Sustainable Tourism, 19(1), 17-34.

Scott, D., Hall, C. M., \& Gössling, S. (2012). Tourism and climate change: Impacts, adaptation and mitigation. London: Routledge.

Scott, D., Peeters, P., \& Gössling, S. (2010). Can tourism deliver its "aspirational" greenhouse gas emission reduction targets? Journal of Sustainable Tourism, 18(3), 393-408.

Semenza, J.C., Hall, D.E., Wilson, D.J., Bontempo, B.D., Sailor, D.J., \& George, L.A. (2008). Public perception of climate change: Voluntary mitigation and barriers to behavior change. American Journal of Preventative Medicine, 35(5), 479-487.

Sharpley, R. (2003). Tourism, Tourists and Society. Huntingdon: Elm.

Steg, L., \& Vlek, C. (2009). Encouraging pro-environmental behaviour: An integrative review and research agenda. Journal of Environmental Psychology, 29, 309-317.

Sustainable Aviation (2011). Progress Report 2011. Retrieved 7 May 2013 from http://www.sustainableaviation.co.uk/progress-report/.

Tung, V.W.S., \& Ritchie, J.R.B. (2011). Exploring the essence of memorable tourism experiences. Annals of Tourism Research, 38(4), 1367-1386.

Turner, V. (1982). From Ritual to Theatre: The Human Seriousness of Play. PAJ: New York.

Vaughan, G. M., \& Hogg, M. A. (2002). Introduction to Social Psychology. 3rd edition. Frenches Forest: Pearson Education.

Whitmarsh, L., Seyfang, G., \& O’Neill, S. (2011). Public engagement with carbon and climate change: To what extent is the public "carbon capable"? Global Environmental Change, 21, 56-65.

Zeppel, H. (2012). Collaborative governance for low-carbon tourism: Climate change initiatives by Australian tourism agencies. Current Issues in Tourism, 15(7), 603-626. 